\title{
Molecular characterization, expression, polymorphism of NR5A2 and its relationship with litter size in Hu sheep
}

\author{
Y.X. Li ${ }^{1,3}$, J. Zhang ${ }^{1,3}$, Y. Qian ${ }^{1,3}$, C.H. Meng ${ }^{1,3}$, H.L. Wang ${ }^{1,3}$, X.J. Tao ${ }^{4}$, \\ S. Zhong ${ }^{1,3}$, S.X. Cao ${ }^{1,3}$ and Q.F. $\mathrm{Li}^{2}$ \\ ${ }^{1}$ Institute of Animal Science, Jiangsu Academy of Agricultural Sciences, \\ Nanjing, China \\ ${ }^{2}$ College of Animal Science and Technology, Nanjing Agricultural University, \\ Nanjing, China \\ ${ }^{3}$ Key Laboratory of Animal Breeding and Reproduction, \\ Jiangsu Academy of Agricultural Sciences, Nanjing, China \\ ${ }^{4}$ Hailun Sheep Industry Limited Company, Jiangyan, China \\ Corresponding authors: Y.X. Li / S.X. Cao \\ E-mail: liyxmh@126.com / caoshaoxian@163.com
}

Genet. Mol. Res. 14 (4): 12765-12775 (2015)

Received April 23, 2015

Accepted July 23, 2015

Published October 19, 2015

DOI http://dx.doi.org/10.4238/2015.October.19.20

ABSTRACT. NR5A2 has been implicated in processes as diverse as steroidogenesis, cellular proliferation, ovarian follicular development, ovulation, and fertility in mammals. However, data about the relationship between NR5A2 and prolificacy in mammals are lacking. In the present study, we identified and characterized NR5A2 of Hu sheep, and investigated the correlation between NR5A2 and reproductive performance. The full-length coding region was $1488 \mathrm{bp}$, and the gene was conserved in mammals. We found a positive correlation between NR5A2 mRNA levels in the ovary and the ovulation rate and litter size of Hu sheep. We detected two single nucleotide polymorphisms (T40C and T1419C) in the coding sequence of NR5A2. At the third and average parity, litter size of Hu ewes with $\mathrm{CC}$ genotype at T40C locus was larger than those of ewes with TT 
or TC genotypes; at the T1419C locus, Hu ewes with TT genotype was greater than those of ewes with $\mathrm{CC}$ genotype at the third parity. Our findings demonstrated that NR5A2 was associated with reproductive performance in Hu sheep, a high prolificacy breed.

Key words: Hu sheep; NR5A2; mRNA expression; Single nucleotide polymorphism; Reproductive performance

\section{INTRODUCTION}

NR5A2, also known as fetoprotein transcription factor (FTF) and liver receptor homolog-1 $(\mathrm{LRH}-1)$, is a member of the nuclear hormone receptor (NR) subfamily of transcription factors (Galarneau et al., 1996; Lu et al., 2000), and plays important roles in embryonic development, cell differentiation, bile acid metabolism and steroidogenesis (Schoonjans et al., 2002; Labelle-Dumais et al., 2007; Yazawa et al., 2010; Winkler et al., 2010). Like other NRs, NR5A2 is comprised of four domains: DNA binding (DBD) and ligand binding (LBD) domains; a long hinger (HR), that bridges the DBD and LBD; and, a modification domain (MD) (Yumoto et al., 2012).

Human NR5A2 was identified in 1993 (Becker-André et al., 1993), and has since been detected in rats (Boerboom et al., 2000) and bovines (Taniguchi et al., 2009) as well as other species. In adult mammals, NR5A2 is predominantly expressed in pre-adipocyte cells and in the liver, intestine, pancreas, ovary and testis (Falender et al., 2003; Liu et al., 2003), and is particularly highly expressed in ovaries (Zhao et al., 2007; Yang et al., 2009). Further study showed that NR5A2 is not expressed in the theca or in stromal cells, but is restricted to the granulosa and luteal cells (Fayad et al., 2004). NR5A2 knockout mice (NR5A2-/-) died between 6.5 and 7.5 days of gestation and the fecundity of heterozygous mice (NR5A2+/-) was significantly decreased (LabelleDumains et al., 2007). Mice lacking NR5A2 in granulosa cells (NR5A2 gc-/-) were sterile owning to anovulation, suggesting this gene is an essential and pleiotropic regulator of ovarian follicular development and ovulation (Duggavathi et al., 2008). Zhang et al. (2013) found mice lacking NR5A2 exclusively in cells of the corpus luteum have ovarian dysfunction and pregnancy failure, illustrating the critical role of NR5A2 in the uterus in mice. Kisspeptin neuron-specific NR5A2 knockout mice (NR5A2 kiss-1-/-) have significantly reduced litter sizes (Atkin et al., 2013). In the ovary, NR5A2 regulates genes involved in follicular development, such as CYP11A1 (Hsieh et al., 2009); STAR (Taniguchi et al., 2009); HSD3B2 (Peng et al., 2003); INHA (Matulis and Mayo, 2012); and FDX1 (Imamichi et al., 2013). NR5A2 is expressed in the anterior pituitary, and regulates key genes underlying follicular development such as those encoding GnRHR (gonadotropin-releasing hormone receptor), LHR (luteinizing hormone receptor), and FSHR (follicle stimulating hormone receptor) (Zheng et al., 2007).

To date, NR5A2 has only been studied in a few mammals including humans (BeckerAndréet al., 1993; Bianco et al., 2014), mice (Zhang et al., 2013; Mamrosh et al., 2014), rats (Lai et al., 2014) and cattle (Taniguchi et al., 2009). Little is known about the relationship between NR5A2 and prolificacy in mammals. In this study, we report the identification and characterization of NR5A2 in Hu sheep, a famous breed in China characterized by high prolificacy with an average litter size of 2.29 lambs. We also determined the relationships between ovarian mRNA level, polymorphisms, and reproductive performance (ovulation rate and litter size). Here, we provide evidence for its role in mammal offspring production. 


\section{MATERIAL AND METHODS}

\section{Samples}

Ten healthy Hu ewes were chosen from Hailun Sheep industry Co., Ltd., of Jiangsu province in China. Ewes were intramuscularly injected with sodium chloride forefront alcohol and the oestrus time of sheep were reorded. When the second natural estrus after 18 days, estrus was identified by the vaginal examination method, and then euthanized within 24 to $36 \mathrm{~h}$ after their second natural estrus. At euthanasia, the ovaries of each ewe were removed. The ovulation points (or number of corpus lutea) were determined, and the ovulation rate recorded. Heart, hypothalamus, liver, uterus, duodenum, fallopian, kidney, spleen, lung, ovary and muscle tissue samples were collected and immediately placed in liquid nitrogen, then stored at $-70^{\circ} \mathrm{C}$ until total RNA was extracted for gene cloning and mRNA expression analysis. Ear tissue samples were obtained from $239 \mathrm{Hu}$ ewes from Hailun, and transported to the laboratory on wet ice. Experiments were performed in accordance with the National Institute of Health guide for the care and use of laboratory animals (National Research Council (US) Committee for the Update of the Guide for the care and use of laboratory animals, 2011).

\section{DNA and RNA extraction}

Genomic DNA and RNA were extracted using a standard phenol-chloroform extraction protocol and a TRIzol Reagent Kit (Invitrogen, Carlsbad, CA, USA), repectively. Agarose gel electrophoresis and ultraviolet spectrophotometry were used to assess RNA quality. Random primers were used for total RNA transcription, and reverse transcription (RT) product was stored at $-20^{\circ} \mathrm{C}$ until further processing.

\section{Cloning and sequencing}

Polymerase chain reactions (PCRs) were performed in a total volume of $20 \mu \mathrm{L}$, containing $1 \mu \mathrm{L}$ RT product; $2 \mathrm{U}$ Taq DNA polymerase (TakaRa, Shiga, Japan); $2 \mu \mathrm{L} 10 \mathrm{X}$ PCR buffer; $0.5 \mathrm{mM}$ dNTP; $2.5 \mathrm{mM} \mathrm{MgCl}$; and $0.5 \mu \mathrm{L}$ upstream and downstream primers (10 nM; Table 1). Amplification conditions were as follows: $94^{\circ} \mathrm{C}$ for $4 \mathrm{~min} ; 94^{\circ} \mathrm{C}$ for $30 \mathrm{~s}, 55^{\circ} \mathrm{C}$ for $30 \mathrm{~s}$, and $72^{\circ} \mathrm{C}$ for $30 \mathrm{~s}$ for 35 cycles; and $72^{\circ} \mathrm{C}$ for $7 \mathrm{~min}$. Amplification products were separated and visualized by agarose gel electrophoresis, and purified with a DNA gel extraction kit (Karroten, Nanjing, China). Recovered DNA fragments were ligated into pMD18-T vectors and transformed into Escherichia coli DH5a. Plasmids were extracted from positive clones with a plasmid DNA extraction kit (Karroten, Nanjing, China), and then sequenced at Shanghai Majorbio Co. (Shanghai, China).

\section{Bioinformatics analysis}

NR5A2 and deduced amino acid (aa) sequences were analyzed using DNASTAR program (DNASTAR, Inc., Madison, WI USA). Sequence alignment was performed with ClustalX 1.81 using default parameters (Thompson et al., 1997). The open reading frame (ORF) was predicted using NCBI ORF Finder (http://www.ncbi.nlm.nih.gov/projects/gorf/). The online database tool ExPASy (http://us.expasy.org/cgi-bin/protparam) was used to analyze aa composition as well as the physical and chemical protein properties. Signal peptide and domain prediction were performed 
using SMART (http://smart.embl-heidelberg.de). The online tool Target P1.1 server (http://www. cbs.dtu.dk/services/TargetP) was used to predict the subcellular localization of protein. The protein structure prediction server PSIPRED (http://bioinf.cs.ucl.ac.uk/psipred/psiform.html) was used to predict protein secondary structure. The tertiary protein structure was predicted using the online tool SWISS-MODEL (http://swissmodel.expasy.org//SWISS-MODEL.html). Phylogenetic analysis was performed using Mega 5.1 software (Tamura et al., 2011) and the neighbor-joining (NJ) method with bootstrap analysis (bootstrap test) with 1000 times repeates (bootstrap percentage, BP) (Thompson et al., 1994; Feng et al., 2015).

\begin{tabular}{|c|c|c|c|c|c|}
\hline Primer & Gene & Primer sequence $\left(5^{\prime}-3^{\prime}\right)$ & $\operatorname{Tm}\left({ }^{\circ} \mathrm{C}\right)$ & Size (bp) & Usage \\
\hline P1 & NR5A2 & $\begin{array}{l}\text { F: TGGTTCACGGAAAGGAGGGC } \\
\text { R: CTATGCTCGTTTTGCGTGCAG }\end{array}$ & 54 & 443 & cDNA clone \\
\hline P2 & NR5A2 & $\begin{array}{l}\text { F: AGCACGGACTTACACCTATT } \\
\text { R: CTCCTTTCCGTGAACCACTTG }\end{array}$ & 51 & 1019 & cDNA clone \\
\hline P3 & NR5A2 & $\begin{array}{l}\text { F: ATGTCTTCTAATTCGGATACT } \\
\text { R: GAGGCAGAGTGGATGTTCTGA }\end{array}$ & 61 & 521 & cDNA clone \\
\hline P4 & NR5A2 & $\begin{array}{l}\text { F: GCGTTGTCCTTACTGTCG } \\
\text { R: GGCTTGGATCACCTTAGAC }\end{array}$ & 60 & 199 & Real-time PCR \\
\hline P5 & $\beta$-actin & $\begin{array}{l}\text { F: AGCCTTCCTTCCTGGGCATGGA } \\
\text { R: GGACAGCACCGTGTTGGCGTAGA }\end{array}$ & 68 & 113 & Real-time PCR \\
\hline P6 & NR5A2 & $\begin{array}{l}\text { F: CTCTAAACCAAAGGACTGCC } \\
\text { R: AACACAACTGGAAAAGCAGTG }\end{array}$ & 60 & 221 & SNP genotype (PCR-RFLP) \\
\hline P7 & NR5A2 & $\begin{array}{l}\text { F1: GGCCGAGGAGTACCTGTACTAC } \\
\text { F2: GGCCGAGGAGTACCTGTACTAT } \\
\text { R: GTTCAATCCATGTTGCTTGG }\end{array}$ & 56 & 213 & SNP genotype (AS-PCR) \\
\hline
\end{tabular}

AS-PCR = allele-specific PCR; RFLP = restriction fragment length polymorphism.

\section{Real-time PCR}

The expression level of NR5A2 in ovarian tissue of Hu sheep was assessed using a real-time PCR instrument (ABI, Foster City, CA, USA). Each $20-\mu \mathrm{L}$ reaction consisted of $1 \mu \mathrm{L} R T$ product; $10 \mu \mathrm{L}$ SYBR Premix ExTaq ${ }^{\mathrm{TM}}$ enzyme (Takara, Dalian, China); $0.5 \mu \mathrm{L}$ each upstream and

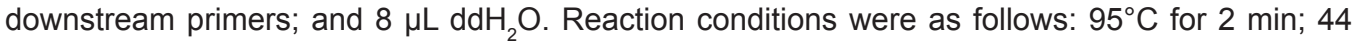
cycles of $95^{\circ} \mathrm{C}$ for $10 \mathrm{~s}, 60^{\circ} \mathrm{C}$ for $N R 5 A 2$ or $68^{\circ} \mathrm{C}$ for $\beta$-actin for $20 \mathrm{~s}$, and $72^{\circ} \mathrm{C}$ for $10 \mathrm{~s}$; and $72^{\circ} \mathrm{C}$ for $5 \mathrm{~min}$. Reactions were assessed by melting curves and were normalized against the housekeeping gene $\beta$-actin. Reactions were repeated in triplicate for each sample.

\section{SNP screening and genotyping}

We screened NR5A2 coding sequences for SNPs using a DNA pooling sequencing assay with primers P1-3 (Table 1). Next, $5 \mu \mathrm{L} 100 \mathrm{ng} / \mu \mathrm{L}$ DNA was collected from the ten sheep and pooled. PCR products were sequenced in both directions. SNPs were identified using Chromas v2.31 (Technelysium Pty Ltd., South Brisbane Australia) and DNA star v7.0 software (DNASTAR, Inc. Madison, WI USA). SNPs were genotyped by restriction fragment length polymorphism (RFLP) or allele-specific (AS) PCR. For PCR-RFLP, $20 \mu \mathrm{L}$ volumes contained $50 \mathrm{ng}$ genomic DNA, $2 \mu \mathrm{L}$ buffer, $1.4 \mu \mathrm{L} \mathrm{Mg}{ }^{2+}, 0.5 \mu \mathrm{L}$ each primer, and $0.2 \mu \mathrm{L}$ Taq DNA polymerase. The cycling protocol was as follows: $5 \mathrm{~min}$ at $95^{\circ} \mathrm{C} ; 35$ cycles of $94^{\circ} \mathrm{C}$ for $30 \mathrm{~s}, 60^{\circ} \mathrm{C}$ for $30 \mathrm{~s}$, and $72^{\circ} \mathrm{C}$ for $20 \mathrm{~s}$; and a final cycle of $72^{\circ} \mathrm{C}$ for $10 \mathrm{~min}$. PCR products $(5 \mu \mathrm{L})$ using different primer pairs were mixed with $0.7 \mu \mathrm{L}$ 10X buffer; $2.5 \mathrm{U}$ restriction enzyme (Msel); and $3.8 \mu \mathrm{L}$ sterilized $\mathrm{ddH}_{2} \mathrm{O}$, and incubated for $3 \mathrm{~h}$ at 
$65^{\circ} \mathrm{C}$. Digested products were subjected to $3 \%$ agarose $(\mathrm{w} / \mathrm{v})$ gel electrophoresis and genotypes were observed. For AS-PCR, specific primers were designed at SNP sites and included two forward and one reverse primer (Table 1). Bases at the $3^{\prime}$ ends of the two forward primers corresponded to the two SNP sequences, and the reverse primer was normally designed (Liu et al., 2012).

\section{Statistical analysis}

Allele frequencies, heterozygosity $\left(H_{\mathrm{E}}\right)$, and polymorphism information content (PIC) were calculated using PopGene v1.31 software (http://www.ualberta.ca/ fyeh/fyeh). Linkage disequilibrium was estimated using SHEsis software. Univariate analysis in the general linear model procedure of SPSS16.0 software was used to analyze the quantitative results and the association between various genotypes and litter size. Multiple comparisons of the means were performed using the least significant difference method, and the model applied was:

$$
Y_{\mathrm{ikm}}=\mu+G_{\mathrm{i}}+P_{\mathrm{k}}+E_{\mathrm{ikm}}
$$

In the above formula, $Y_{\text {ikm }}$ is the trait measured on each of the $i \mathrm{~km}^{\text {th }}$ animal; $\mu$ is the average litter size of each animal; $G_{i}$ is the fixed effect associated with ith genotype or combinative genotype; $P_{\mathrm{k}}$ is the fixed effect associated with parities; and $E_{\mathrm{ikm}}$ is the random error.

\section{RESULTS}

\section{Identification and characterization of NR5A2 of Hu sheep}

The full-length coding region of Hu sheep NR5A2 was $1488 \mathrm{bp}$, which was submitted to GenBank (accession No. JN182926). The coding region was $96.98 \%$ homologous to that of cattle, $88.37 \%$ homologous to humans, and $73.62 \%$ homologous to zebrafish at the nucleotide level. By blasting in $\mathrm{NCBI}$, we found $\mathrm{Nr} 5 \mathrm{a} 2$ gene comprised at least seven exons and six introns, and was located at 76960-77100 kbp within NW_004080175.1 on chromosome 12 of sheep (Ovis aries).

The NR5A2 protein of Hu sheep contained 495 aa residues (Figure 1A); the relative molecular weight was $56.20 \mathrm{kDa}$ and the isoelectric point 8.09. Using BLAST, we found that the Hu sheep NR5A2 protein was highly homologous at the aa level to that of cattle (98.38\%) and humans $(96.77 \%)$, but was only $76.98 \%$ homologous with that of zebrafish, indicating that NR5A2 is relatively conserved in mammalian species. We constructed a phylogenetic tree of mammals based on the aa sequences of NR5A2; clustering of genes on the tree was consistent with the traditional species classification (Figure 1B). Only 18 aa were represented in the NR5A2 protein sequence, of which Pro was the most abundant (11.27\%); Pyl and Sec were absent. We detected 55 positively and 52 negatively charged aa residues. In vitro protein half-life was $30 \mathrm{~h}$, and the instability coefficient was 50.24. The grand average of hydropathicity (GRAVY) was -0.362 , suggesting that the NR5A2 protein was strongly hydrophilic. Our analysis did not predict a signal peptide, nor was NR5A2 predicted to be a secretory or transmembrane protein. The protein was mainly localized in the nucleus.

Further analysis indicated that sheep NR5A2 contained three conserved domains - a DNA-binding (DBD; Cys40 - Leu132); an Ftz-F1 box (Ala109-Ala138); and a ligand-binding (LBD) domain (Ala255-Ser495; Figure 1A). To further characterize the protein, we predicted its three- 
dimensional structure using the SWISS-MODEL website online tool (http://swissmodel.expasy. org//SWISS-MODEL.html) according to the neural network homology modeling method and PyMol software for visualization, we found that NR5A2 contained 11 a-helices, $2 \beta$-folds, and some random curls (Figure 1C).

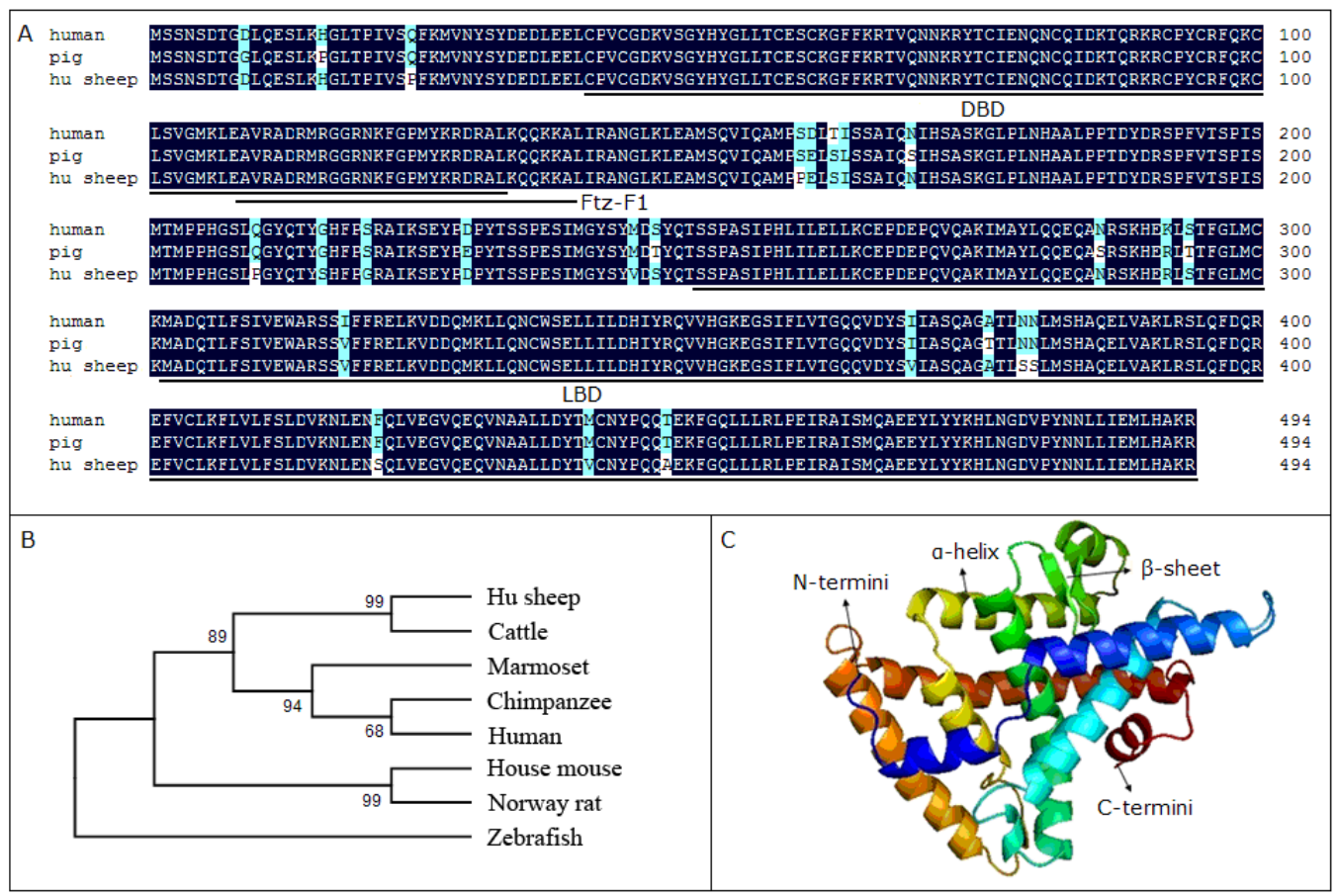

Figure 1. Identification of NR5A2 in Hu sheep. Alignment of Hu sheep NR5A2 protein with human (NP_003813) and pig (AFD98842). Black boxes indicate positions at which residues are identical, and grey boxes highlight residues that are similar. Functional domains and motifs are underlined (A). A neighbor-joining tree of mammals was constructed based on the amino acid sequences of NR5A2 protein (B). 3-D structure of NR5A2 protein in Hu sheep (C).

\section{NR5A2 mRNA level is significantly associated with reproductive performance}

We evaluated the expression pattern of NR5A2 in 11 tissue types from Hu sheep by RT$\mathrm{PCR}$, and found it was widely expressed in the heart, hypothalamus, liver, uterus, duodenum, fallopian, kidney, ovary, spleen, lung and muscle tissues, and was particularly highly expressed in the ovary (Figure 2A). To further investigate the relationship between NR5A2 and reproductive performance of Hu sheep, the mRNA level of NR5A2 in ovaries was also evaluated. There was a positive correlation between the NR5A2 mRNA level in ovaries and ovulation rate $(r=0.8125$; Figure 2B), and the litter size ( $r=0.7092$; Figure 2C).

\section{NR5A2 contains two point mutations in Hu sheep}

To search for SNPs in Hu sheep NR5A2, we used pooled DNA resequencing of the full coding region. Two SNPs, T40C and T1419C, were identified (Figure 3A and B). At the T40C locus, 
we detected three genotypes (TT, CT, and CC) using the PCR-RFLP method (Figure 3C), and their genotype frequencies were $0.137,0.751$, and 0.111 , respectively (Table 2 ). The allele frequencies $C$ and T were 0.487 and 0.513 , respectively. The PIC (Polymorphism information content) was 0.375 . The T40C site was in Hardy-Weinberg disequilibrium $(P<0.05)$. We also detected three genotypes (TT, CT, and CC) at T1419C using AS-PCR (Figure 3D); the genotype frequencies were 0.115 , 0.823 , and 0.062 , respectively (Table 2 ). The $C$ and $T$ allele frequencies were 0.473 and 0.527 , respectively. The PIC was 0.374 , and the site was in Hardy-Weinberg disequilibrium $(P<0.01)$.
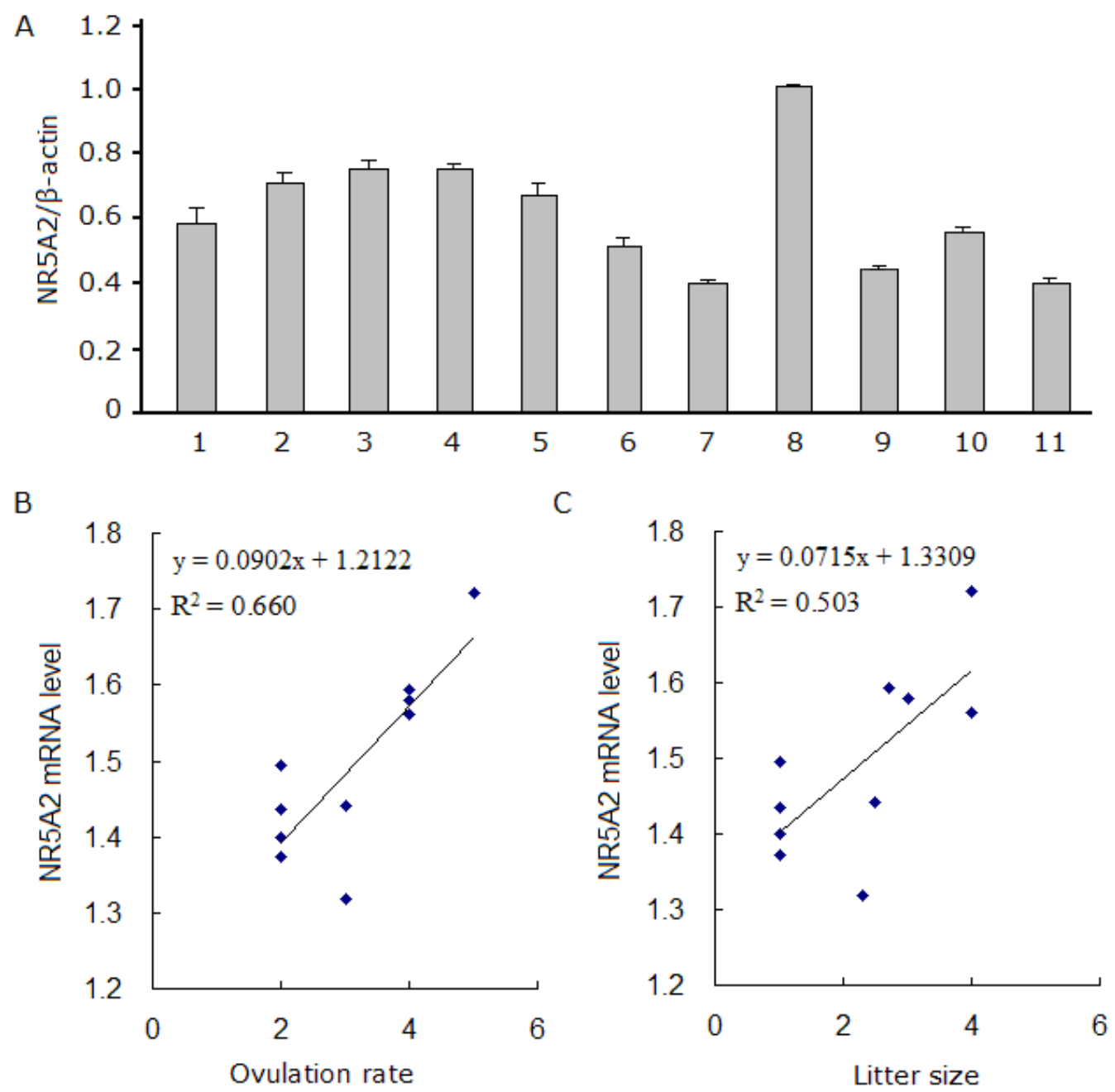

Figure 2. Relationship between NR5A2 mRNA level and reproductive performance of Hu sheep. Tissue mRNA expression profiles of NR5A2, 1-11 indicate heart, hypothalamus, liver, uterus, duodenum, fallopian, kidney, ovary, spleen, lung and muscle samples (A). Relationship between NR5A2 mRNA level and ovulation rate (B) and between NR5A2 mRNA level and litter size (C). 
A

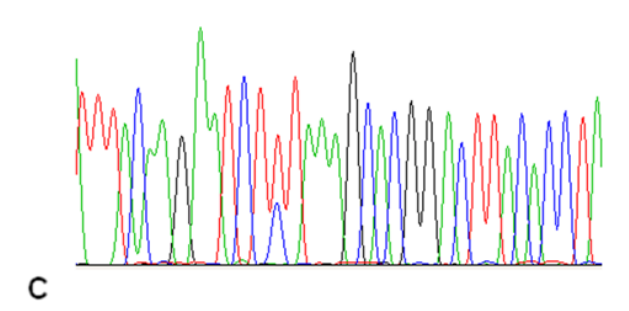

B

D
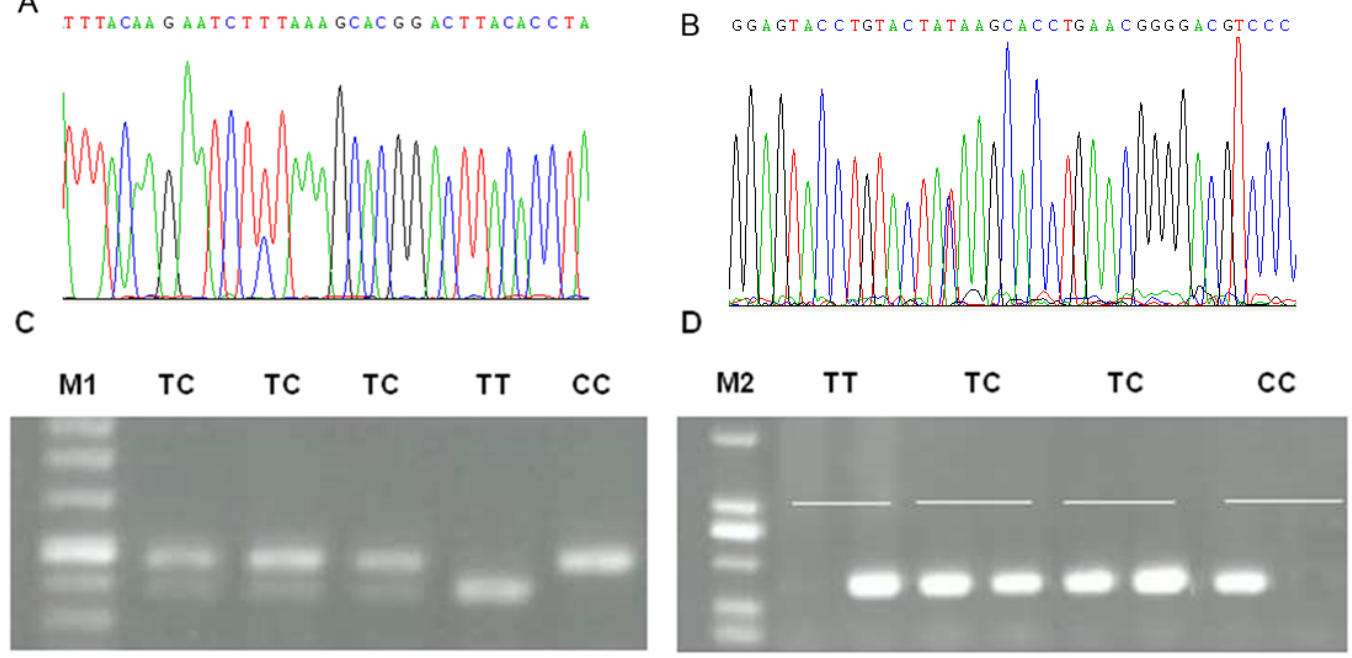

Figure 3. SNP identification and genotyping of NR5A2 coding region. T40C (A) and T1419C (B) locus sequencing maps and genotype map enzyme by Msel for T40C locus (C). AS-PCR electrophoresis map for T1419C locus (D).

Table 2. Genetic characteristics of two SNP loci in NR5A2.

\begin{tabular}{|c|c|c|c|c|c|c|c|}
\hline \multirow[t]{2}{*}{ SNP } & \multicolumn{3}{|c|}{ Genotype frequency } & \multicolumn{2}{|c|}{ Allele frequency } & \multirow[t]{2}{*}{ PIC } & \multirow[t]{2}{*}{$H_{\mathrm{E}}$} \\
\hline & $\mathrm{CC}$ & $\mathrm{TC}$ & TT & C & $\mathrm{T}$ & & \\
\hline $\mathrm{T} 40 \mathrm{C}$ & 0.110 & 0.755 & 0.135 & 0.487 & 0.513 & 0.375 & 0.500 \\
\hline T1419C & 0.062 & 0.823 & 0.115 & 0.473 & 0.527 & 0.374 & 0.497 \\
\hline
\end{tabular}

$\mathrm{PIC}=$ polymorphism information content; $H_{\mathrm{E}}=$ heterozygosity.

\section{Association analysis of independent SNPs with litter size}

The association betweenNR5A2 polymorphisms with litter size in Hu sheep populations was verified. The litter size of Hu ewes with T40C genotype CC $(1.77 \pm 0.08)$ and TC $(1.74 \pm 0.07)$ were greater than that of ewes with genotype TT $(1.49 \pm 0.03$; $P<0.05)$ at the average litter size. Ewes with genotype CC $(2.50 \pm 0.22)$ had larger litter sizes than those of ewes with genotype CT (1.72 \pm $0.16)$ and TT $(1.67 \pm 0.08)$ at the third parity; ewes with genotype CT $(1.81 \pm 0.13)$ had larger litter sizes than those of ewes with genotype CC $(1.67 \pm 0.18)$ and TT $(1.40 \pm 0.05)$ at the second parity (Table 3). At the T1419C locus, individuals with the TT genotype had larger litter sizes than those with genotype $C C$ or genotype $C T$, but the difference was significant only at the third parity $(P<0.05)$.

Table 3. Least squares mean for litter size of different genotypes of NR5A2.

\begin{tabular}{lcccccc}
\hline Locus & Genotype & Number & 1st parity litter size & 2nd parity litter size & 3rd parity litter size & Average litter size \\
\hline T40C & CC & 27 & $1.71 \pm 0.12^{\mathrm{a}}$ & $1.67 \pm 0.18^{\mathrm{ab}}$ & $2.50 \pm 0.22^{\mathrm{a}}$ & $1.77 \pm 0.08^{\mathrm{a}}$ \\
& CT & 179 & $1.69 \pm 0.1^{\mathrm{a}}$ & $1.81 \pm 0.13^{\mathrm{a}}$ & $1.72 \pm 0.16^{\mathrm{b}}$ & $1.74 \pm 0.07^{\mathrm{ab}}$ \\
& TT & 33 & $1.60 \pm 0.05^{\mathrm{a}}$ & $1.40 \pm 0.05^{\mathrm{b}}$ & $1.67 \pm 0.08^{\mathrm{bc}}$ & $1.49 \pm 0.03^{\mathrm{c}}$ \\
T1419C & TT & 27 & $1.73 \pm 0.18^{\mathrm{a}}$ & $1.58 \pm 0.18^{\mathrm{a}}$ & $2.00 \pm 0.25^{\mathrm{a}}$ & $1.83 \pm 0.14^{\mathrm{a}}$ \\
& TC & 197 & $1.68 \pm 0.05^{\mathrm{a}}$ & $1.74 \pm 0.07^{\mathrm{a}}$ & $1.73 \pm 0.08^{\mathrm{ab}}$ & $1.67 \pm 0.05^{\mathrm{a}}$ \\
& CC & 15 & $1.62 \pm 0.17^{\mathrm{a}}$ & $1.67 \pm 0.14^{\mathrm{a}}$ & $1.33 \pm 0.26^{\mathrm{b}}$ & $1.58 \pm 0.15^{\mathrm{a}}$ \\
\hline
\end{tabular}

Values with different superscripts within the same column in particular locus differ significantly $(P<0.05)$. 


\section{DISCUSSION}

NR5A2 is involved in a variety of processes including ovulation and embryo differentiation and development (Fayard et al., 2004; Hsieh et al., 2009; Yazawa et al., 2010; Winkler et al., 2010). Hinshelwood et al. (2005) found that NR5A2 plays a role in gonadal development, the initiation of folliculo genesis, and regulation of estrogen biosynthesis within the ovary. NR5A2 has a great impact on animal reproductive performance (Hinshelwood et al., 2005; Duggavathi et al., 2008; Atkin et al., 2013). Duggavathi et al. (2008) found that female mice with granulosa cell-specific deletions of NR5A2 are sterile, due to anovulation. Specific-knockout of NR5A2 in ovarian corpus cells induces ovarian dysfunction and eventually leads to pregnancy failure (Zhang et al., 2013), and mice with hypothalamic arcuate nucleus with kisspeptin neuron-specific deletion of NR5A2 have been found to have significantly reduced litter sizes (Atkin et al., 2013). In this study, we cloned and characterized the full-length coding sequence of NR5A2 of Hu sheep. We detected high homology between $\mathrm{Hu}$ sheep and other mammals for both the nucleotide and aa sequences, suggesting conservation of mammalian NR5A2 during evolution. Furthermore, like other mammals, Hu sheep NR5A2 has three classic conserved functional domains - DBD, Ftz-F1 box, and LBD (Li et al., 1998; Fayard et al., 2004). For members of the NR5A family, specific binding to DNA is determined by the Ftz-F1 box domain, a 26-aa region adjacent to the C-terminus of the DBD domain (Ueda et al., 1992). Together, these results indicate that $N R 5 A 2$ is highly conserved in mammals, and that Hu sheep NR5A2 may contribute to female reproduction and reproductive development, as is the case for other mammals (Labelle-Dumains et al., 2007; Guo et al., 2010).

In mammals, NR5A2 is expressed mainly in the liver, intestine, pancreas and ovary (Falender et al., 2003), and has been detected in other tissues such as the hypothalamus and duodenum, indicating that it may play an important role in other tissues and organs (Baquié et al., 2011). In the current study, we found that NR5A2 was widely expressed in various tissues and was highly expressed in the ovary, consistent with previous reports (Falender et al., 2003). We found a positive correlation between NR5A2 mRNAs level in the ovary and ovulation rate and litter size, suggesting that NR5A2 was involved in regulating reproductive performance. NR5A2 knockout mice died at day 6.5-7.5 of gestation, and the fecundity of heterozygous mice decreased significantly (Labelle-Dumains et al., 2007). Mice lacking NR5A2 in granulosa cells were sterile owning to anovulation (Duggavathi et al., 2008). Together, these data suggest that NR5A2 plays an important role in animal ovulation and reproduction (Labelle-Dumains et al., 2007; Duggavathi et al., 2008; Wang et al., 2013).

Hu sheep are a famous, highly prolific breed in China, and the molecular mechanism of its high fecundity has been a topic of interest for domestic scholars. At present, IGF1 (He et al., 2012), FSHR (Chu et al., 2012a), KISS-1/GPR54 (Chu et al., 2012b), PPNR (Guan et al., 2011), INHBB (Chu et al., 2011a) and BMPR-IB (Chu et al., 2011b) have been identified as candidate genes affecting Hu sheep fecundity. However, until now, no gene with a major effect on reproduction has been identified. NR5A2 research has mainly focused on correlations between SNPs and pancreatic cancer (Rizzato et al., 2011; Tang et al., 2014), and no studies have been reported that examine the relationship between NR5A2 SNPs and reproduction in domestic animals. We identified two SNPS - T40C and T1419C - in the coding region of Hu sheep NR5A2, and found that the T40C locus was indeed correlated with litter size. We also found that the T1419C locus was located in the LBD region, furthermore, like the T40C locus, this polymorphism change the aa from Leu to lle, and the molecular mechanism underlying the effect on litter size of Hu sheep needs to further research. 
In the present study, we found the full coding sequence of NR5A2 was 1488 bp and was conserved in mammals. There was a positive correlation between the mRNA level of NR5A2 in ovary and ovulation rate and litter size. T40C and T1419C loci were detected in the coding sequence of NR5A2. Association analysis showed that the T40C SNP could be used as a genetic marker for selecting individuals with higher litter sizes in Hu sheep.

\section{Conflicts of interest}

The authors declare no conflicts of interest.

\section{ACKNOWLEDGMENTS}

Research supported by the Jiangsu Agricultural Science and Technology Innovation Fund (grant \#CX(14)5031), the Natural Science Foundation of Jiangsu Province (grant \#BK20140750) and the Natural Science Foundation of China (\#31501934).

\section{REFERENCES}

Atkin SD, Owen BM, Bookout AL, Cravo RM, et al. (2013). Nuclear receptor LRH-1 induces the reproductive neuropeptide kisspeptin in the hypothalamus. Mol. Endocrinol. 27: 598-605.

Baquié M, St-Onge L, Kerr-Conte J, Cobo-Vuilleumier N, et al. (2011).The liver receptor homolog-1 (LRH-1) is expressed in human islets and protects \{beta\}-cells against stress-induced apoptosis. Hum. Mol. Genet. 20: 2823-2833.

Becker-André M, André E and DeLamarter JF (1993). Identification of nuclear receptor mRNAs by RT-PCR amplification of conserved zinc-finger motif sequences. Biochem. Biophys. Res. Commun. 194: 1371-1379.

Bianco S, Brunelle M, Jangal M, Magnani L, et al. (2014). LRH-1 governs vital transcriptional programs in endocrine-sensitive and -resistant breast cancer cells. Cancer Res. 74: 2015-2025.

Boerboom D, Pilon N, Behdjani R, Silversides DW, et al. (2000). Expression and regulation of transcripts encoding two members of the NR5A nuclear receptor subfamily of orphan nuclear receptors, steroidogenicfactor-1 and NR5A2, in equine ovarian cells during the ovulatory process. Endocrinology 141: 4647-4656.

Chu M, Zhuang H, Zhang Y, Jin M, et al. (2011a). Polymorphism of inhibin $\beta B$ gene and its relationship with litter size in sheep. Anim. Sci. J. 82: 57-61.

Chu M, Jia L, Zhang Y, Jin M, et al. (2011b). Polymorphisms of coding region of BMPR-IB gene and their relationship with litter size in sheep. Mol. Biol. Rep. 38: 4071-4076.

Chu MX, Guo XH, Feng CJ, Li Y, et al. (2012a). Polymorphism of 5' regulatory region of ovine FSHR gene and its association with litter size in small tail Hansheep. Mol. Biol. Rep. 39: 3721-3725.

Chu M, Xiao C, Feng T, Fu Y, et al. (2012b). Polymorphisms of KiSS-1 and GPR54 genes and their relationships with litter size in sheep. Mol. Biol. Rep. 39: 3291-3297.

Duggavathi R, Volle D H, Mataki C, Antal MC, et al. (2008). Liver receptor homolog 1 is essential for ovulation. Genes Dev. 22: 1871-1876.

Falender AE, Lanz R, Malenfant D, Belanger L, et al. (2003). Differential expression of steroidogenic factor-1 and FTF/LRH-1 in the rodent ovary. Endocrinology 144: 3598-3610.

Fayard E, AuwerxJ and Schoonjans K (2004). LRH-1: an orphan nuclear receptor involved in development, metabolism and steroidogenesis. Trends Cell Biol. 14: 250-260.

Feng Q, Gong GG, Yang Z, Chun XH, et al. (2015). Molecular cloning and expression profiling of a chalcone synthase gene from Lamiophlomis rotata. J. Genet. 94: 193-205.

Galarneau L, Pare JF, Allard D, Hamel D, et al. (1996). The alpha1-fetoprotein locus is activated by a nuclear receptor of the Drosophila FTZ-F1 family. Mol. Cell Biol. 16: 3853-3865.

Guan F, Pan L, Li J, Tang H, et al. (2011). Polymorphisms of the prion protein gene and their effects on litter size and risk evaluation for scrapie in Chinese Hu sheep. Virus Genes 43: 147-152.

He JN, Zhang BY, Chu MX, Wang PQ, et al. (2012). Polymorphism of insulin-like growth factor 1 gene and its association with litter size in small tail Han sheep. Mol. Biol. Rep. 39: 9801-9807.

Hinshelwood MM, Shelton JM, Richardson JA and Mendelson CR (2005). Temporal and spatial expression of liver receptor 
homologue-1 (LRH-1) during embryogenesis suggests a potential role in gonadal development. Dev. Dyn. 234: 159-168. Hsieh HT, Wang CH, Wu ML, Yang FM, et al. (2009). PIASy inhibits LRH-1-dependent CYP11A1 expression by competing for SRC-1 binding. Biochem. J. 419: 201-209.

Imamichi Y, Mizutani T, Ju Y, Matsumura T, et al. (2013). Transcriptional regulation of human ferredoxin 1 in ovarian granulosa cells. Mol. Cell Endocrinol. 370: 1-10.

Labelle-Dumais C, Paré JF, Bélanger L, Farookhi R et al. (2007). Impaired progesterone production in NR5A2+/- mice leads to a reduction in female reproductive function. Biol. Reprod. 77: 217-225.

Lai WA, Yeh YT, Fang WL, Wu LS, et al. (2014). Calcineurin and CRTC2 mediate FSH and TGFß1 upregulation of Cyp19a1 and Nr5a in ovary granulosa cells. J. Mol. Endocrinol. 53: 259-270.

Li M, Xie YH, Kong YY, Wu X, et al. (1998). Cloning and characterization of a novel human hepatocyte transcription factor, hB1F, which binds and activates enhancer II of hepatitis B virus. J. Biol. Chem. 273: 29022-29031.

Liu DL, Liu WZ, Li QL, Wang HM, et al. (2003). Expression and functional analysis of liver receptor homologue 1 as a potential steroidogenic factor in rat ovary. Biol. Reprod. 69: 508-517.

Liu J, Huang S, Sun M, Liu S, et al. (2012). An improved allele-specific PCR primer design method for SNP marker analysis and its application. Plant Methods 8: 34 .

Lu TT, Makishima M, Repa JJ, Schoonjans K, et al. (2000). Molecular basis for feedback regulation of bile acid synthesis by nuclear receptors. Mol. Cell 6: 507-515.

Mamrosh JL, Lee JM, Wagner M, Stambrook PJ, et al. (2014). Nuclear receptor LRH-1/NR5A2 is required and targetable for liver endoplasmic reticulum stress resolution. Elife 3: e01694.

Matulis CK and Mayo KE (2012). The LIM domain protein FHL2 interacts with the NR5A family of nuclear receptors and CREB to activate the inhibin- $\alpha$ subunit gene in ovarian granulosa cells. Mol. Endocrinol. 26: 1278-1290.

National Research Council (US) Committee for the Update of the Guide for the Care and Use of Laboratory Animals (2011). Guide for the care and use of laboratory animals. 8th edn. National Academies Press, Washington.

Peng N, Kim JW, Rainey WE, Carr BR, et al. (2003). The role of the orphan nuclear receptor, liver receptor homologue-1, in the regulation of human corpus luteum 3beta-hydroxysteroid dehydrogenase type II. J. Clin. Endocr. Metab. 88: 6020-6028.

Rizzato C, Campa D, Giese N, Werner J, et al. (2011). Pancreatic cancer susceptibility loci and their role in survival. PLoS One 6: e27921.

Schoonjans K, Annicotte JS, Huby T, Botrugno OA, et al. (2002). Liver receptor homolog 1 controls the expression of the scavenger receptor class B type I. EMBO Rep. 3: 1181-1187.

Tamura K, Peterson D, Peterson N, Stecher G, et al. (2011). MEGA5: molecular evolutionary genetics analysis using maximum likelihood, evolutionary distance, and maximum parsimony methods. Mol. Biol. Evol. 28: 2731-2739.

Taniguchi H, Komiyama J, Viger RS and Okuda K (2009). The expression of the nuclear receptors NR5A1 and NR5A2 and transcription factor GATA6 correlates with steroidogenic gene expression in the bovine corpus luteum. Mol. Reprod. Dev. 76: 873-880.

Thompson JD, Gibson TJ, Plewniak F, Jeanmougin F, et al. (1997). The CLUSTAL-X windows interface: flexible strategies for multiple sequence alignment aided by quality analysis tools. Nucleic Acids Res. 25: 4876-4882.

Ueda H, Sun GC, Murata T and Hirose S (1992). A novel DNA-binding motif abuts the zinc finger domain of insect nuclear hormone receptor FTZ-F1 and mouse embryonal long terminal repeat-binding protein. Mol. Cell Biol. 12: 5667-5672.

Wang LH, Zhang W, Ji JL, Gao QX, et al. (2013). Molecular characterization and expression analysis of the Lrh-1 gene in Chinese Hu sheep. Genet. Mol. Res. 12: 1490-1500.

Winkler N, Bukulmez O, Hardy DB and Carr BR (2010). Gonadotropin releasing hormone antagonists suppress aromatase and anti-Müllerian hormone expression in human granulosa cells. Fertil. Steril. 94: 1832-1839.

Yang FM, Pan CT, Tsai HM, Chiu TW, et al. (2009). Liver receptor homolog-1 localization in the nuclear body is regulated by sumoylation and CAMP signaling in rat granulosa cells. FEBS J. 276: 425-436.

Yazawa T, Inaoka Y, Okada R, Mizutani T, et al. (2010). PPAR-gamma coactivator-1alpha regulates progesterone production in ovarian granulosa cells with SF-1 and LRH-1. Mol. Endocrinol. 24: 485-496.

Yumoto F, Nguyen P, Sablin EP, Baxter JD, et al. (2012). Structural basis of coactivation of liver receptor homolog-1 by ß-catenin. Proc. Natl. Acad. Sci. U. S. A. 109: 143-148.

Zhang C, Large MJ, Duggavathi R, DeMayo FJ, et al. (2013). Liver receptor homolog-1 is essential for pregnancy. Nat. Med. 19: 1061-1066.

Zhao H, Li Z, Cooney AJ and Lan ZJ (2007). Orphan nuclear receptor function in the ovary. Front. Biosci. 12: 3398-3405.

Zheng W, Yang J, Jiang Q, He Z, et al. (2007). Liver receptor homologue-1 regulates gonadotrope function. J. Mol. Endocrinol. 38: 207-219. 